\title{
USING SONG AS MEDIA IN TEACHING ENGLISH
}

\author{
SYAMSIAH DEPALINA SIREGAR, M.Pd \\ Lecturer of English Department on Muhammadiyah University of South Tapanuli
}

dsyamsiah@yahoo.com

\begin{abstract}
This study was aimed at first investigating whether or not the use of songs significantly give effect as media in teaching English. Second, the difficulties faced by the students in learning English were also investigated. This quasi experimental research involved two classes of students of agriculture in UMTS. The data were collected through pretest, posttest and questionnaires. In analyzing the collected data, quantitative research method was employed. Furthermore, the data taken from questionnaires were also investigated to find out the difficulties faced by the students in using songs as media in learning English. The study found that the use of songs likely improves students' motivation in learning English. It was evidenced by tobt (6.542) that greater than tcrit. As the result of the study, the null hypothesis of this research was rejected; the use of songs is likely to give effecct in learning English.
\end{abstract}

Keywords: Songs, media, teaching English

\section{Introduction}

English is one of compulsory subject from primary up to high education. Many students still dislike with English. They said that English is difficult lessson. The number of English language speakers and the demand for students is growing at an exponential rate. Ongoing learning that is student centered and engaging promotes success and gives students a competitive edge as they develop and retain students skills and content. Music lyrics and songs not only provide tools to strengthen and reinforce vocabulary, comprehension, listening, speaking and writing, but increase learning and grammatical variations with auditory skills and rhythmic patterns that stimulate brain activity and encourage imagination.

Learning with music and song is supported by integrating complex interactive roles creating a positive environment with high levels of student achievement. Action research supports a connection between language and song, as wstudents as actively engaging learners in stimulating activities and discovery. This publication outlines strategies for using songs, song parody and lyrics to introduce and strengthen students in the context of musical patterns, melodies, 
rhymes and creative vocabulary. Once students engage in students through music lyrics, the next step is to customize learning by composing their own lyrics and, for the capable and creative, set their lyrics to original self-composed melodies.

The value of songs for language teaching and learning is, thus, viewed somewhat controversially. However, ultimately we know very little about how songs are actually used in the language classroom. While teachers' recommendations, lesson plans and anecdotal accounts are a valuable source of information and insight, they cannot replace a more thorough empirical investigation of teachers' beliefs and teaching practices. Language instructors are at the centre of pedagogical decision-making and the implementation of methodological approaches in the L2-classroom, and it is essential to get a better understanding of their views and experiences. Until now, however, only few studies have explored the use of songs in language teaching from the point of view of the teachers (Edwards, 1997; Bjorklund, 2002; Pérez Aldeguer \& Leganés Lavall, 2012). Unfortunately, while providing some interesting first insight, the few existing studies have been limited in scope and in the number of participants. In ISSN 2541-3775 addition, they did not explore the details of actual classroom practices. A focus on teachers, their views, thoughts and beliefs but also their teaching practices locates this study in the vicinity of teacher cognition research, that is, research into "what teachers think, know, and believe and the relationship of these mental constructs to what teachers do in the language classroom" (Borg, 2003, p. 81).

Murphey (1990) suggested that many English teachers have long recognized that song and music work well in language classes. The statement shows that teachers can use song as a media to overcome the students difficulties in listening and improve their listening ability. Creative teacher can also use songs to teach English through songs since they provide a break from the textbook and work book. It is new and interesting for them. Therefore, with this situation, they will be motivated especially in learning English. Therefore, the present study is aimed to investigate the use of songs as media in teaching English. Furthermore, the researcher expects that this research will give contribution to motivate students in learning English in the future.

\section{Methodology}

- Sample 
For the purpose of the study and in an attempt to answer the hypothesis, 120 students of second semester in agriculturer department of UMTS were selected as the sample of the research. Two classes were chosen for this research by applying purposive sampling. Each class consist of sixty students. Furthermore, both classes were tested by pre and posttest. During the experiment, the experimental group was given several treatments in period of six meetings.

\section{- Instrumentation}

The following instruments were used in this study:

1. English worksheet; this test was used to evaluate the students' mastery in comprehend grammar in English. It comprised 50 question items which given to the students as pilot test. The validity of the instrument is valid in level of $r=0.790$ which has minimum value 0.393. As an addition for this research, the reliability of the test was also analyzed. The valid and reliable items then used as pre-test and post-test and become the next research instrument.
2. A researcher-made questionnaire to seek the difficulties faced by the students in listening comprehension using songs as the media. It included 8 questions concerning on the students' difficulties in the teaching and learning process using songs.

- Design and Procedure

This research was conducted based on quantitative method. The research used quasi experimental design. The sample is divided into two classes; experimental class and control class. Both classes were tested by pre-test and post-test. Before giving the post-test, songs were given to the experimental class as the treatment. Besides, the control class was taught by conventional methods; the researcher taught listening by explaining through english worksheet. Afterwards, the data which are taken from experimental class and control class were compared and analyzed to find out its significance. The data were analyzed by using $t$ test formula to determine the means score of two classes so that the effectiveness of the use of songs could be sought.

- Data Analysis 
The data were analyzed based on the following analysis:

The validity and reliability of the instrument was firstly drawn. Based on the calculation, the instrument is valid with $\mathrm{r}=0.790$. Furthermore the reliability of the instruments was also analyzed, from the calculation, it is shown that the reliability value r11 is 0.304. From the calculation, it can be concluded that the intrument is reliable since the minimum value of the reliability of the instrument is 0.257

After knowing the validity and reliability of the instrument, then paired sample t-test formula was conducted to know the effect of the use of songs. Before doing so, it is necessary to compute the pre-test score of each group which consisted of normality distribution test, variance homogeneity test and t-test computation.

\section{Data Presentation and Discussion}

Considering the obtained value of $t$ (tobt $=6.542$ ) is higher than the value of $t$ critical (tcrit $=2.021$ ). Thus the null hypothesis was rejected and the use of songs as the media of teaching English is likely improve the students' ability in English. This finding supports the research hypothesis that the use of song is effective in improving students' English ability. Hence, it can be concluded that result the pre-test and posttest scores of experimental are different and there was an improvement in the students' ability in English.

However, to answer the second question of the research about the difficulties faced by the students towards songs as the media in teaching English, the data taken from questionnaire were analyzed. It can be seen that the students thought that English comprehension is difficult. From 63 students, most of the students agreed that English comprehension is difficult. How the teacher explains the material is not a problem for the students. It was evidenced by the amount of students who agreed with that statement. Besides, the real situation in the classroom observed by the researcher had proven the statement that the teacher's way of teaching is not become the difficulties for the students. Since the learning activities held in the classroom, the difficulties may be faced by students in comprehending comprehension using song is dealing with noisy classroom. It shows that the noisy classroom become one of the difficulties faced by the students. In this research, the treatment given to the experimental group takes place in an ordinary class. As the 
result, the noises from other classes disrupt the classroom activities. Finding a way to overcome this situation also becomes challenge for the teacher when using song for the media of teaching English. The use of language laboratory would be necessary when the teacher wants to use songs as the media of teaching.

The data gained from the questionnaire also showed that fast paced songs become another difficulties faced by the students. The teacher's creativity in developing the material, in this case song, is needed. The teacher may follow the principles criteria when they choose song as media of teaching English. As it stated by Coromina, (2000) and Lynch, (2005), songs must have clear and understandable lyric. The teacher is suggested to choose songs which are understandable; not too fast in term of rhythm so that the students could follow the material based on what they hear from the songs. Furthermore, the different accent of the singer became one of the difficulties faced by the students in listening comprehension using songs.

For that reason, it is important for the teacher to select appropriate songs which can help the students learn the language and gain learning objectives.
To overcome this problem, the teacher should find the song which is not too fast and understandable. The finding was in line with Coromina, (2000) and Lynch (2005), who stated that songs must have clear and understandable lyric and they suggested avoiding those kind of song in teaching listening ability through song. The researcher also believed that replaying the songs could overcome this difficulty.

\section{Conclusion}

The media of teaching and learning process, in this case songs, not only help the teacher to teach English but also provide and interesting way for the students to achieve the learning goals. The media has contributed a lot in making the students understand well the delivered lesson. The content of the songs may become one of influential factors which may determine the improvement of the students' ability in English. The use of songs also should consider students' need so that it will help students to learn and achieve the learning objective. The teacher ability in selecting teaching material will also influence the use of songs in improving the students' English ability. 


\section{References}

Beal, M, L, et al. (2008). State of the Context: Listening in Education. Routledge, Taylor \& Francis Group, LLC

Coromina, I, S. (2000). An Original Approach to the Teaching of Songs in the

Classroom. Retrieved on December 1, 2011 from http: //exchanges state. gov /english teaching /forum

Kirwan, M. (2009). Veterinary Communication Skills. Oklahoma: Blackwell Publishing Ltd.

Lynch, M, L. (2005). Using Popular Song to Improve language Listening Comprehension Skills. Retrieved on November 29, 2011 from http://ezinearticles.com/?UsingPopular-Songs-to-ImproveLanguage-ListeningComprehensionSkills\&id=104984

Murphey, T (1990). Song and Music in Language learning. New York: Bern, Frankfurt and Main.

Schwart, A, M. (1998). Listening in a foreign language: Modules for the professional preparation of teaching assistants in foreign languages. Washington DC: Grace Stovall Burkhart, ed.

Snell, J. (1999). Improving TeacherStudent Interaction in the EFL Classroom: An Action Research Report. Retrieved on November 7 2011 from http://iteslj.org/Articles/SnellInteraction.html
Wallace et al. (2004). Teaching Speaking, Listening, and Writing, an International Academy of Education journal. Retrieved on November $7 \quad 2011$ from http://www.curtin.edu.au/curtin/de pt/smec/iae ole. 
